\title{
A New Control Method of Current Balancer for Single-Phase Three-Wire Secondary Distribution Systems Using the Correlation and Cross-Correlation Coefficients
}

\author{
Hirokazu Fukui Student Member (Yamaguchi University, h.fukui@pe-news1.eee.yamaguchi-u.ac.jp) \\ Eiji Hiraki Member (Yamaguchi University, hiraki@yamaguchi-u.ac.jp) \\ Toshihiko Tanaka Senior Member (Yamaguchi University, totanaka@yamaguchi-u.ac.jp) \\ Shinji Fukuma Non-member (University of Fukui, fukuma@fuis.fuis.fukui-u.ac.jp)
}

Keywords: single-phase three-wire secondary distribution system, current balancer, correlation coefficient, cross-correlation coef-

ficient, active-reactive current, unbalanced condition

This paper proposes a new control method of the previously proposed current balancer for single-phase secondary distribution feeders using the correlation and cross-correlation coefficients. The basic principle of the proposed method is discussed in detail, and then confirmed by digital computer simulation using PSIM software. A prototype experimental model is constructed and tested to verify the validity and practicability of the proposed control method.

Figure 1 shows a circuit diagram of the constructed experimental model. The three-leg PWM converter that performs the current balancer is connected in parallel to the loads. The source voltage $v_{S}$, the load currents $i_{L 1}$ and $i_{L 2}$ are detected, and the components of the load currents correlative and cross-correlative to the primary side voltage waveform, which correspond to the active and reactive currents, are calculated in each feeder in a DSP (digital signal processor: TMS320C671333). These reactive and unbalanced-active components are compensated on the source side. The balanced source

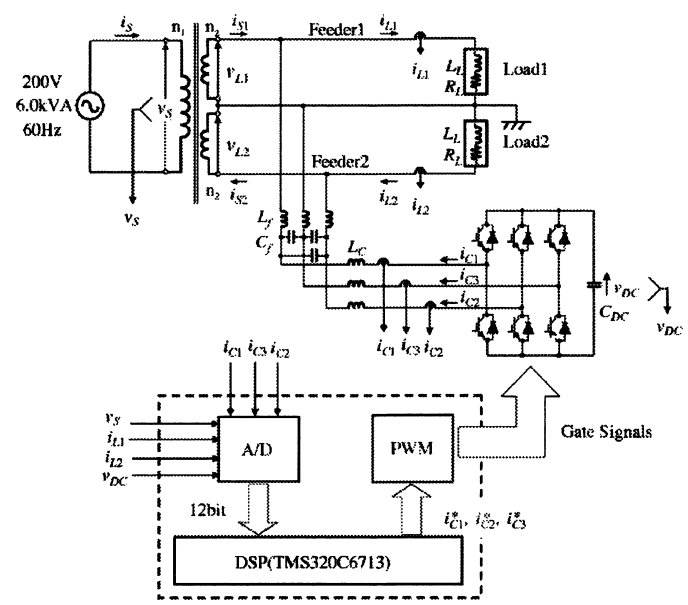

Fig. 1. Circuit diagram of the constructed experimental model of the proposed current balancer in single-phase secondary distribution feeders currents with the power factor of 0.9 are obtained in each feeder.

Figure 2 shows the experimental results for Fig. 1, where the unbalanced loads are connected. Before the current balancer was started, the source currents $i_{S 1}$ and $i_{S 2}$ were unbalanced, and their power factors were different, respectively. After the current balancer was started, the source currents $i_{S 1}$ and $i_{S 2}$ were balanced with the power factor of 0.9 in spite of the unbalanced load currents $i_{L 1}$ and $i_{L 2}$. In the proposed control method, the power factors on the source side were 0.9 because all reactive power was not compensated. Thus the required-rating of the PWM converter was reduced by one-half as compared to that of the current balancer, where the previously proposed control method was applied. The capacity of the dc capacitor $C_{D C}$ was also reduced by one-half. The authors concluded that the proposed current balancer with the newly proposed control method is useful for the practical applications.

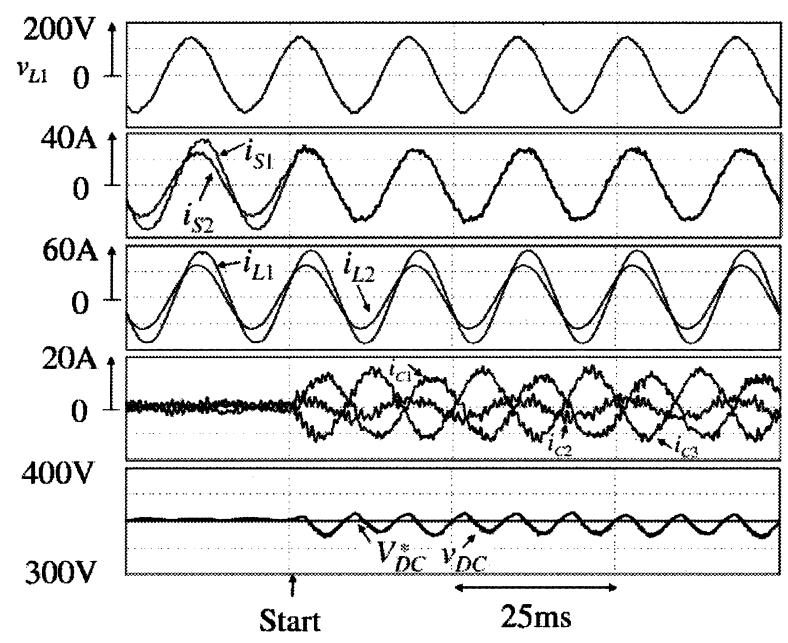

Fig. 2. Experimental waveforms for the constructed experimental model of Fig. 1 


\title{
電源電圧と負荷電流の相関と相互相関に着目した 単相三線式配電用電流バランサの制御法
}

\author{
学生員 福井 博一* 正員 平木 英治* \\ 上級会員 田中 俊彦* 非会員 福間 慎治**
}

\author{
A New Control Method of Current Balancer for Single-Phase Three-Wire Secondary \\ Distribution Systems Using the Correlation and Cross-Correlation Coefficients \\ Hirokazu Fukui*, Student Member, Eiji Hiraki*, Member, \\ Toshihiko Tanaka*, Senior Member, Shinji Fukuma**, Non-member
}

This paper proposes a new control method of the current balancer for single-phase three-wire secondary distribution systems using the correlation and cross-correlation coefficients. The components of the load currents correlative and cross-correlative to the primary side voltage waveform, which correspond to the active and reactive currents, are detected in each feeder, then the reactive and unbalanced-active components are compensated on the source side. The balanced currents with the variable power factor are obtained in each feeder. The basic principle of the proposed method is discussed in detail, and then confirmed by digital computer simulation. A proto-type experimental system is constructed and tested. Experimental results demonstrate that the balanced source currents with the power factor of 0.9 are obtained in spite of unbalanced load currents.

キーワード：単相三線式配電，電流バランサ，相関係数，相互相関係数，有効-無効電流，不平衡状態

Keywords: single-phase three-wire secondary distribution system, current balancer, correlation coefficient, cross-correlation coefficient, active-reactive current, unbalanced condition

\section{1. まえがき}

家庭などの低圧配電として単相三線式配電が広く用いら れているが(1), アンバランスな負荷状態による両電圧線電 流の不平衡が問題となる。電流の大きさの違いによって生 じる電圧不平衡を解消するため，一般に線路の末端に巻数 比 1 の単巻変圧器によるバランサを設置し, 電圧を等しく する方法が用いられている(2)。

著者らは先に，3レグ電圧形 PWM インバータを用いた 単相三線式配電用電流バランサを提案し，その有効性を明 らかにした ${ }^{(3)}$ 。これは, 各フィーダ間の有効電力は直流キャ パシタを介することなくインバータ内で授受される点に特 徵がある。このため, 先に提案されている方式に比較し,

\footnotetext{
* 山口大学大学院 理工学研究科 情報・デザイン工学系専攻 干 755-8611 宇部市常盤台 2 丁目 16-1

Department of Electrical and Electronic Engineering, Yamaguchi University

2-16-1, Tokiwadai, Ube 755-8611

** 福井大学 工学部 情報メディア工学科

干 910-8507 福井市文京 3-9-1

Department of Information Science, The University of Fukui

3-9-1, Bunkyou, Fukui 910-8507
}

直流キャパシタ容量を大幅に低減することができる点に特 長がある。電流バランサの制御法として電源電圧と負荷電 流の相関に着目した方式を提案した ${ }^{(4)}$ 。これにより，電源 側で力率が 1 でバランスした電源電流を得ることができる が, 電流バランサにより電源側での無効電力がゼロとなる よう負荷の無効電力を全て補償するため, 変換器容量が大 きくなる問題点があった。

本論文では，電流バランサとして動作する電圧形 PWM インバータの变換器容量の低減を目的として, 電源電圧と 負荷電流の相関および相互相関に着目した制御法を提案す る ${ }^{(5)}$ 。これは, 負荷電流の無効電流成分を制御することで 任意の力率を有する電源電流を得ることができる点に特長 がある。はじめに, 相関および相互相関関数を用いた電流 バランサの制御法について詳細に検討する。次に, 電圧形 PWM インバータの電力フローを検討し, 先に提案されて いる方式に比べ直流キャパシ夕容量を大幅に低減可能であ ることを明らかにする。計算機シミュレーションおよび実 験結果より，提案した制御法の有効性を確認する。計算機 シミュレーション結果および実験結果から, 先に提案した 方式に比較し大幅に変換器容量および直流キャパシタ容量 を低減しながら, 電気供給約款 ${ }^{(6)}$ で定められた力率 0.9 の 


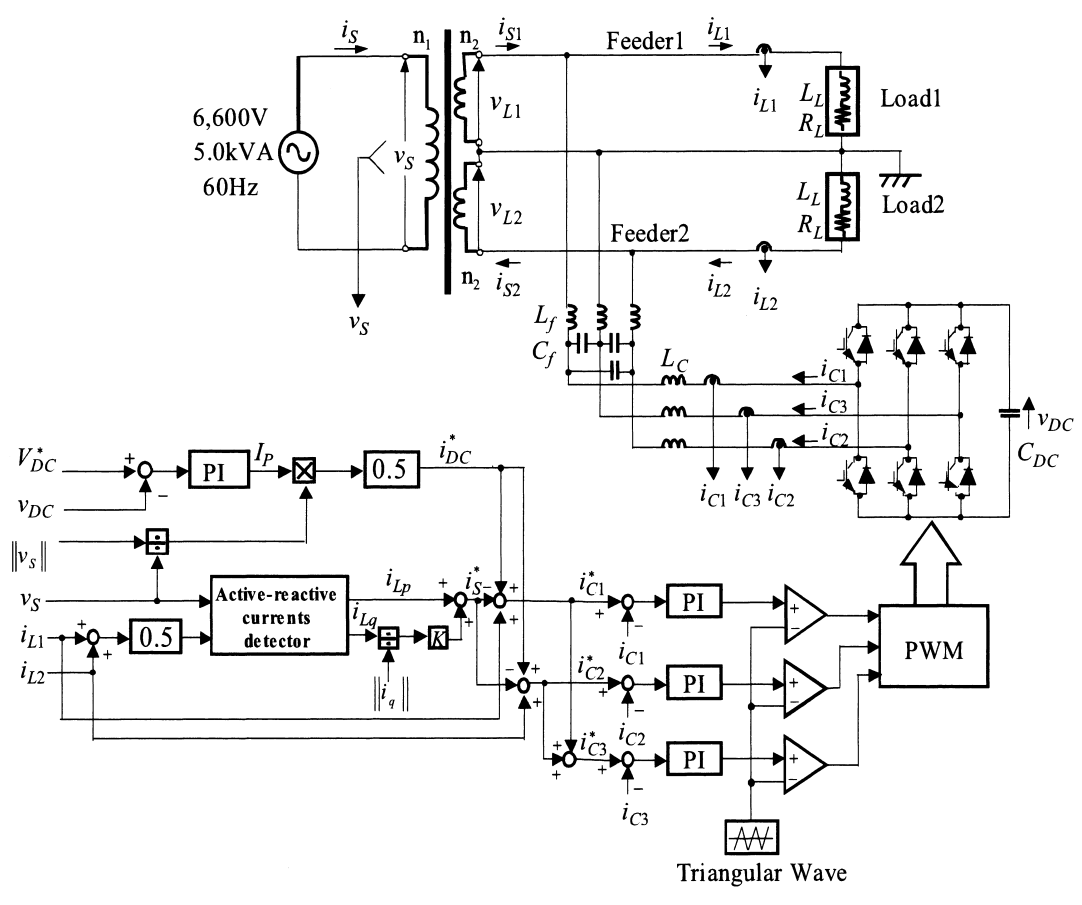

図 1 単相三線式配電用電流バランサの構成図

Fig. 1. Circuit diagram of the proposed current balancer in single-phase three-wire secondary distribution systems.

バランスした電源電流が得られることを明らかにする。

\section{2. 単相三線式配電用電流バランサ}

〈2・1〉 システム構成図 1 に, 単相三線式配電用電 流バランサのシステム構成図を示す。配電卜ランスの高圧 側は $6,600 \mathrm{~V}, 60 \mathrm{~Hz} ， 5.0 \mathrm{kVA}$ をべースとしており，低圧 側の定格は $105 \mathrm{~V}, 24 \mathrm{~A}$ である。低圧側巻線は，家庭に電 力を配電するために用いられ，負荷として線形負荷を考慮 している。電流バランサには 3 レグ電圧形 PWM インバー 夕を用いており，各レグがフィーダ 1 , フィーダ 2 および中 性線にそれぞれ接続されている。電圧形 PWM インバータ は，負荷側電流の無効電流成分と有効電流成分のアンバラ ンス分を補償する。このため, 電源側で電気供給約款 ${ }^{(6)}$ で 定められた，力率が 0.9 でバランスした電流を得ることが できる。文献 (7) および (8) では，単相電圧形ハーフブリッ ジ PWM インバータを 2 台用いており, 直流キャパシタの 中性点を利用して中性線の電流を供給している。各フィー ダの有効電力は直流キャパシタを介して授受されるため, キャパシタ電圧の脈動が大きくなり，これを抑制するため大 容量の直流キャパシタが必要となる。さらに, 各直流キャ パシタに流出入する電力が等しくならないため，それぞれ の直流キャパシタの電圧変動が異なるという問題点がある。 本提案方式では，3レグの電圧形 PWM インバータを使用 することで，これらの問題を解決している。

$\langle\mathbf{2} \cdot \mathbf{2}\rangle$ 電源電圧と負荷電流の相関と相互相関に着目した 電流バランサの制御法図 1 において, 高圧側電圧 $v_{S}(t)$ および負荷電流 $i_{L 1}(t), i_{L 2}(t)$ の和の $1 / 2$ 倍の電流 $i_{L}(t)$ が次
式で与えられるものとする。

$$
\begin{aligned}
v_{S}(t) & =\sqrt{2} V \sin \omega t \\
i_{L 1}(t) & =\sqrt{2} I_{1} \sin \left(\omega t-\phi_{1}\right) \\
i_{L 2}(t) & =\sqrt{2} I_{2} \sin \left(\omega t-\phi_{2}\right) \\
i_{L}(t) & =\frac{1}{2}\left\{i_{L 1}(t)+i_{L 2}(t)\right\} \\
& =\sqrt{2} I_{L} \sin (\omega t-\phi) .
\end{aligned}
$$

ここで, 関数空間において, $v_{S}(t), i_{L}(t)$ のノルムはそれぞ れ次式で与えられる。

$$
\begin{aligned}
\left\|v_{S}(t)\right\| & =\sqrt{\frac{1}{T_{S}} \int_{t-T_{S}}^{t} v_{S}^{2}(t) d t} \\
\left\|i_{L}(t)\right\| & =\sqrt{\frac{1}{T_{S}} \int_{t-T_{S}}^{t} i_{L}^{2}(t) d t} .
\end{aligned}
$$

ただし， $T_{S}=1 / 60[\mathrm{~s}]$ である。積分時間は， $T_{S} / 2$ に短縮 できる ${ }^{(9)}$ 。ノルムは関数の大きさを表し, 実効值に相当す る。 $v_{S}(t)$ と $i_{L}(t)$ の内積は, 次式で与えられる。

$$
\left\langle v_{S}(t), i_{L}(t)\right\rangle=\frac{1}{T_{S}} \int_{t-T_{S}}^{t} v_{S}(t) \cdot i_{L}(t) d t
$$

内積は有効電力に相当する。相関係数 $r$ は内積をノルムの 積で割ることにより次式で表される。

$$
r=\frac{\left\langle v_{S}(t), i_{L}(t)\right\rangle}{\left\|v_{S}(t)\right\|\left\|i_{L}(t)\right\|}
$$

相関係数 $r$ は関数どうしがどの程度似ているかを表す尺度 であり, 大きさは-1 $\leq r \leq 1$ である。この相関係数は力率 
を表す。(2)式，(3) 式および (4) 式を用いることで， $i_{L}(t)$ の有効電流 $i_{L p}(t)$ は次式で表すことができる。

$$
i_{L p}(t)=\frac{\left\langle v_{S}(t), i_{L}(t)\right\rangle}{\left\|v_{S}(t)\right\|^{2}} \cdot v_{S}(t) \cdots
$$

(1) 式を(5) 式に代入すると，次式を得る。

$$
i_{L p}(t)=\sqrt{2} I_{L} \cos \phi \sin \omega t .
$$

次に, 電源電圧 $v_{S}(t)$ の $1 / 4$ 周期前の情報と $i_{L}(t)$ の相互 相関係数を求める。ノルムと内積より相互相関係数 $R$ は次 式で与えられる。

$$
R=\frac{\left\langle v_{S}\left(t-\frac{T_{S}}{4}\right), i_{L}(t)\right\rangle}{\left\|v_{S}\left(t-\frac{T_{S}}{4}\right)\right\|\left\|i_{L}(t)\right\|} .
$$

(2) 式，(3) 式および (7) 式を用いることで， $i_{L}(t)$ の無効電 流 $i_{L q}(t)$ は次式で表すことができる。

$$
i_{L q}(t)=\frac{\left\langle v_{S}\left(t-\frac{T_{S}}{4}\right), i_{L}(t)\right\rangle}{\left\|v_{S}\left(t-\frac{T_{S}}{4}\right)\right\|^{2}} \cdot v_{S}\left(t-\frac{T_{S}}{4}\right) \cdots
$$

（1）式を（8）式に代入すると，次式を得る。

$$
i_{L q}(t)=-\sqrt{2} I_{L} \sin \phi \cos \omega t .
$$

ここで, 電源電流の力率を電気供給約款 (6) で定められ た 0.9 とする指令值の演算法について検討する。図 2 に, 電源電圧，電源電流拈よび負荷電流のフェザー図を示す。 (9) 式で検出した無効電流をノルムで割ることにより基準 波 $i_{q}(t)=-\sqrt{2} \cos \omega t$ を発生する。(6) 式の有効電流 $i_{L p}(t)$ に対して各フィーダの電源電流 $i_{S 1}(t), i_{S 2}(t)$ の力率が 0.9 となるような無効電流を得るためのゲイン $K$ を基準波 $i_{q}(t)$ と乗算する。ただし, 図 2 より $K=I_{L} \cos \phi\left\{\tan \left(\cos ^{-1} 0.9\right)\right\}$ である。電源電流がバランス状態でかつ力率を 0.9 とする ためには $i_{S 1}(t), i_{S 2}(t)$ は次式となればよい。

$$
\begin{aligned}
i_{S 1}(t) & =i_{S 2}(t) \\
& =i_{L p}(t)+K i_{q}(t) \\
& =\sqrt{2} I_{L} \cos \phi\left\{\sin \omega t-\tan \left(\cos ^{-1} 0.9\right) \cos \omega t\right\}
\end{aligned}
$$

したがって, 電流バランサ出力電流指令值は次式となる。

$$
\begin{aligned}
& i_{C 1}^{*}(t)=i_{L 1}(t)-i_{S 1}(t) \\
& i_{C 2}^{*}(t)=i_{L 2}(t)-i_{S 2}(t) \\
& i_{C 3}^{*}(t)=-\left\{i_{C 1}^{*}(t)+i_{C 2}^{*}(t)\right\}
\end{aligned}
$$

図 1 に扔いて, 負荷が変動した場合に有効電力が電圧形 PWM インバータに流出入し直流キャパシタ電圧が変動す る。この対策として, 直流キャパシ夕電圧一定制御ブロッ クを有している。直流キャパシタ電圧の指令值 $V_{D C}^{*}$ と検出 したキャパシタ電圧 $v_{D C}$ の偏差をPI コントローラにより増 幅し，直流キャパシ夕電圧を制御するための有効電流の振 幅 $I_{P}$ を求める。ここで, PI コントローラの伝達関数 $G(s)$

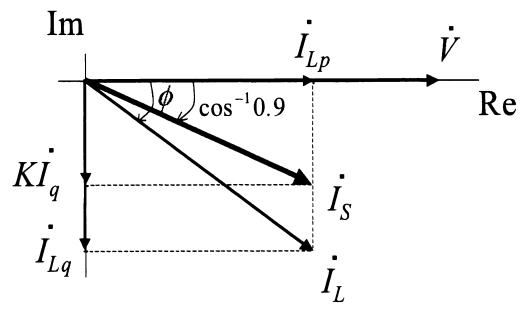

図 2 電源電圧・電流执よび負荷電流の

$$
\text { フェザー図 }
$$

Fig. 2. Phaser diagram of the source voltage, source current and load current.

は次式で与えられる。

$$
G(s)=K_{P}\left(1+\frac{1}{T_{I} S}\right) \cdot
$$

本論文で用いた PI コントローラは $K_{P}=0.1, T_{I}=10 \mathrm{~ms}$ である。一方, 高圧側で検出した $v_{S}$ を電源電圧ノルムで 割った $1 /\left\|v_{s}\right\|$ を乗じることにより, 振幅 $\sqrt{2}$ の基準電圧を 発生する。この基準電圧と $I_{P}$ を乗算することで $v_{D C}$ を一 定に制御するための指令值 $i_{D C}^{*}$ を求める。この $i_{D C}^{*}$ を (11) 式で与えられる電流バランサ出力電流指令值に加えること で, 電流バランサの電流指令值 $i_{C 1}^{*}$ および $i_{C 2}^{*}$ としている。 以上から，直流キャパシタ電圧一定制御法を用いた場合の 電流バランサ出力電流指令值は, 次式で与えられる。

$$
\begin{aligned}
& i_{C 1}^{*}(t)=i_{L 1}(t)-i_{S 1}(t)+0.5 i_{D C}^{*}(t) \\
& i_{C 2}^{*}(t)=i_{L 2}(t)-i_{S 2}(t)+0.5 i_{D C}^{*}(t)
\end{aligned}
$$

\section{3. 電カフローと直流キャパシタ容量の検討}

図 1 において, 電圧形PWM インバー夕の直流キャパシ 夕に流入する電力フローを求め直流キャパシタ容量につい て検討する。ここで, 各フィーダの電源電流 $i_{S 1}(t), i_{S 2}(t)$ が次式で与えられるものとする。

$$
\begin{aligned}
i_{S 1}(t) & =i_{S 2}(t) \\
& =\sqrt{2} I_{S}\left(\sin \omega t-K_{1} \cos \omega t\right)
\end{aligned}
$$

ただし $I_{S}=\frac{1}{2}\left(I_{1} \cos \phi_{1}+I_{2} \cos \phi_{2}\right), K_{1}=\tan \left(\cos ^{-1} 0.9\right)$ である。また，(11) 式より電流バランサの出力電流は次式 となる。

$$
\begin{aligned}
i_{C 1}(t)= & i_{L 1}(t)-i_{S 1}(t) \\
= & \sqrt{2}\left\{\frac{1}{2}\left(I_{1} \cos \phi_{1}-I_{2} \cos \phi_{2}\right) \sin \omega t\right. \\
& \left.-\left(I_{1} \sin \phi_{1}-K_{1} I_{S}\right) \cos \omega t\right\} \\
i_{C 2}(t)= & i_{L 2}(t)-i_{S 2}(t) \\
= & \sqrt{2}\left\{\frac{1}{2}\left(-I_{1} \cos \phi_{1}+I_{2} \cos \phi_{2}\right) \sin \omega t\right. \\
& \left.-\left(I_{2} \sin \phi_{1}-K_{1} I_{S}\right) \cos \omega t\right\}
\end{aligned}
$$

ここで, 低圧側電圧 $v_{L 1}(t)$ と $v_{L 2}(t)$ は次式で与えられるも 
のとする。

$$
v_{L 1}(t)=v_{L 2}(t)=\sqrt{2} V_{L} \sin \omega t
$$

以上より, 電圧形 PWM インバータへ流入する電力 $p_{C}(t)$ は，次式となる。

$$
\begin{aligned}
p_{C}(t) & =p_{C 1}(t)+p_{C 2}(t) \\
& =V_{L}\left(2 K_{1} I_{S}-I_{1} \sin \phi_{1}-I_{2} \sin \phi_{2}\right) \sin 2 \omega t
\end{aligned}
$$

(17) 式より, 電圧形 PWM インバータの直流キャパシタに は無効電力のみが流入し, その周期は $T_{S} / 2$ である。このこ とは, 各フィーダの有効電力は電圧形 PWM インバータを 介して授受が行われ，直流キャパシタには流入しないこと を示している。したがって，文献 (1) および (2) と比較し直 流キャパシタ容量を大幅に低減できる。

次に, 直流キャパシタ容量について検討する。(17) 式よ り, キャパシタの充電および放電期間は $T s / 4$ となる。キャ パシタ電圧の平均值から最大值および最小值となる期間は $T_{s} / 8$ である。ここで，この期間におけるキャパシタへの流 入または流出エネルギー $\Delta W_{C}$ は,

$$
\Delta W_{C}=\int_{0}^{T_{S} / 8} p_{C}(t) d t
$$

となる。

電圧形 PWM インバータへ流入するエネルギーを $\Delta W_{C}$ とすると, 直流キャパシタ電圧の平均值が $V_{D C}$ であるとき, 次式が成立する。

$$
\Delta W_{C}=\frac{1}{2} C\left\{\left(V_{D C}+\Delta V_{D C}\right)^{2}-V_{D C}^{2}\right\}
$$

ただし， $\Delta V_{D C}$ はキャパシタ電圧の平均值からの変動分であ る。 $\operatorname{Load} 1$ に $1.2 \mathrm{pu}$, 力率 $0.8, \operatorname{Load} 2$ に $0.8 \mathrm{pu}$, 力率 0.9 の負荷が接続されている場合に (18) 式で与えられる $\Delta W_{C}$ は $-0.865 \mathrm{~J}$ である。定常状態において，直流キャパシタ電 圧の平均值に対して $\pm 5 \%$ の変動を許容するものとする。直 流キャパシ夕電圧の平均值が $350 \mathrm{~V}$ のき, 直流キャパシ 夕容量は次式となる。

$$
\begin{aligned}
& C=\frac{2 \times(-0.865)}{(350 \times 0.95)^{2}-350^{2}} \\
& =145[\mu \mathrm{F}] \cdots \cdots \ldots \ldots \ldots
\end{aligned}
$$

(20) 式は定常状態における容量であり, 負荷急変時における 電圧変動を $\pm 10 \%$ 以穴するために計算機シミュレーショ ンによりキャパシタ容量を検討した。シミュレーション結 果から，直流キャパシタ容量を $440 \mu \mathrm{F}$ に決定した。これ は，文献(3) と比較し約 $1 / 2$ に低減することができた。

\section{4. シミュレーション結果}

本論文で提案した電流バランサの制御法の有効性を確認 するために，計算機シミュレーションを行った。シミュレー ションには，パワーエレクトロニクス用シミュレータ PSIM
表 1 図 1 の回路定数

Table 1. Circuit constants for Fig. 1.

\begin{tabular}{ll|l}
\hline \hline Load1 & $L_{L}: 5.8 \mathrm{mH}$ & $L_{f}: 1.0 \mathrm{mH}$ \\
\cline { 3 - 3 } & $R_{L}: 2.9 \Omega$ & $C_{f}: 4.7 \mu \mathrm{F}$ \\
\hline Load2 & $L_{L}: 6.3 \mathrm{mH}$ & $L_{c}: 3.0 \mathrm{mH}$ \\
\cline { 3 - 3 } & $R_{L}: 4.9 \Omega$ & $C_{D C}: 440 \mu \mathrm{F}$ \\
\hline
\end{tabular}

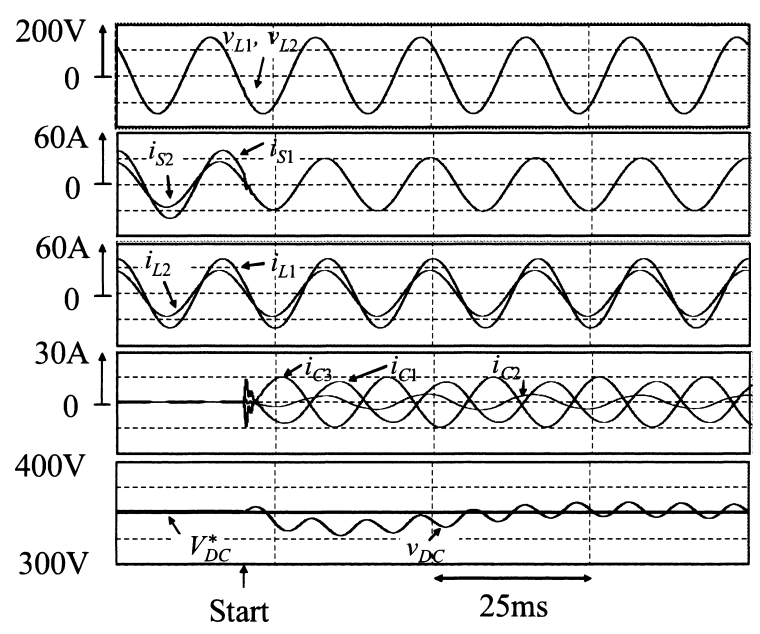

図 3 電流バランサ起動前後のシミュレーション波形

Fig. 3. Simulation waveforms for Fig. 1 before and after started.

を用いた。内線規程では，単相三線式における中性線と各 電圧側電線間の負荷は “やむを得ない場合は設備不平衡率 を 40\%までとすることができる”と定められている(10)。設 備不平衡率とは, 中性線と各電圧側電線間に接続される負 荷設備容量 $S_{1}, S_{2}$ [VA] の差と総負荷設備容量 $S_{A}$ [VA] の 平均值の比で定義される。このとき, 設備不平衡率は次式 で与えられる。

$$
\text { 設備不平衡率 }[\%]=\frac{S_{1}-S_{2}}{S_{A} \times 0.5} \times 100
$$

表 1 に，計算機シミュレーションに用いた回路定数を示す。

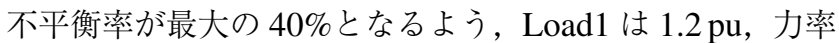
$0.8, \operatorname{Load} 2$ は $0.8 \mathrm{pu}$, 力率 0.9 とした。

〈4・1〉 シミュレーション結果＼cjkstart図 3 に電流バランサ起 動時の波形を示す。 $v_{L 1}$ は低圧側電圧, $i_{S 1}, i_{S 2}$ は各フィー ダの電源電流を示している。電流バランサ起動以前はアン バランスな負荷状態であるためLoad 1 に流れる電流 $i_{L 1}$ と $\operatorname{Load} 2$ に流れる電流 $i_{L 2}$ の振幅および位相が異なっている。 一方, 電流バランサの起動後は, 電源側電流 $i_{S 1}$ と $i_{S 2}$ の 振幅が等しく力率が 0.9 の波形となっている。また，キャ パシタ電圧 $v_{D C}$ から, 直流キャパシタ電圧一定制御法によ り指令值 $V_{D C}^{*}=350 \mathrm{~V}$ 付近に一定に制御されている。図 4 は，Load2 を一定とした状態で Load1 を $1.2 \mathrm{pu}$ から $0.6 \mathrm{pu}$ に急変させた場合のシミュレーション波形を示している。 図 4 より, 負荷が急変した場合においても電流バランサに より各フィーダの電源側電流 $i_{S 1}, i_{S 2}$ はバランスした状態 


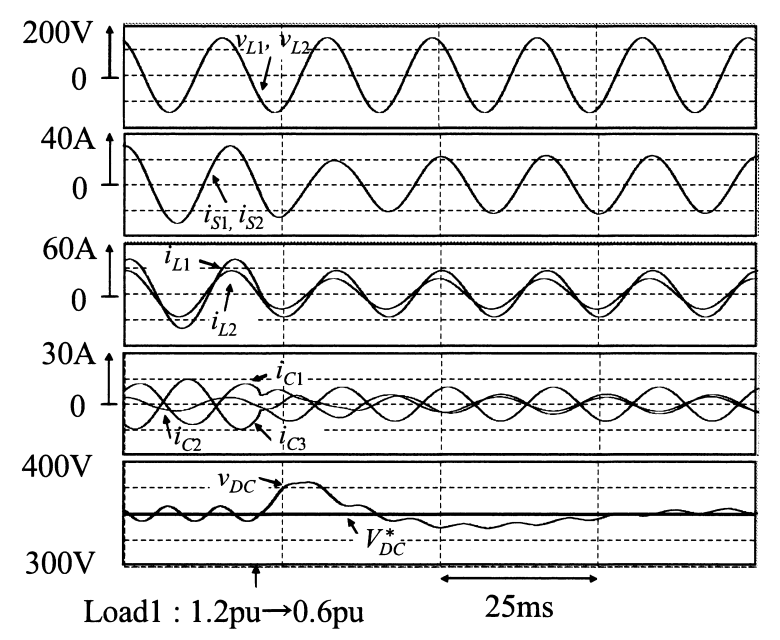

図 4 負荷急変時におけるシミュレーション波形

Fig. 4. Simulation waveforms for Fig. 1 with load variation of the Load1.

となっていることが確認できる。図 3 および図 4 において, 定常状態に打ける直流キャパシ夕電圧の变動率は $\pm 2.1 \%$ で ある。また，負荷急変時では+8.6\%であり，10\%以内となっ ている。変動率が定常状態で $\pm 5 \%$ 以内であり負荷急変時で は $\pm 10 \%$ 以内であることから，決定したキャパシ夕容量の 妥当性が確認できる。

文献 (7), (8)では， $4700 \mu \mathrm{F}$ を直列接続して用いている。 また，先に提案した相関に着目した制御方式を用いた場合 では， $800 \mu \mathrm{F}$ の直流キャパシ夕を用いている(3)。本方式で は，直流キャパシタ容量を大幅に低減できた。

\section{5. 実験結果}

本論文で提案した電流バランサの制御法の有効性を確認 するために，実験装置を構成し実験による検討を行った。

$\langle\mathbf{5} \cdot \mathbf{1}\rangle$ 実験装置の構成図 1 において, 高圧側が $6,600 \mathrm{~V}$ であり, 研究室レベルで実験装置を構成するのは 困難である。そこで，一次側の電圧を $200 \mathrm{~V}$ として実験装 置を構成した。図 5 に, 単相三線式配電用電流バランサの 実験装置構成図を示す。電源トランスの一次側は $200 \mathrm{~V}$, $6.0 \mathrm{kVA}$ である。また，二次側はそれぞれ $100 \mathrm{~V} ， 30 \mathrm{~A}$ と し，それぞれ線形負荷が接続されている。表 2 に図 5 の回 路定数を示す。負荷はアンバランスな負荷状態となるよう, シミュレーションと同様にフィーダ 1 には $1.2 \mathrm{pu}$ で力率が 0.8 の負荷を接続し，フィーダ 2 には $0.8 \mathrm{pu}$ で力率が 0.9 の負荷を接続している。このとき，不平衡率はシミュレー ションと同様に $40 \%$ でる。図 5 に扔いて, 電源電圧 $v_{S}$, 負荷電流 $i_{L 1}, i_{L 2}$ を検出し, $\mathrm{A} / \mathrm{D}$ 変換器を介してデジタル信 号として，DSPに入力する。DSPでは，(11) 式を用いて， 電流バランサの出力電流指令值 $i_{C 1}^{*}, i_{C 2}^{*}, i_{C 3}^{*}$ を演算する。 さらに，三角波比較方式 PWM を用いて，各レグの出力電 流を指令值に追従させている。三角波の周波数は $15 \mathrm{kHz}$ で あり，これらはすべて DSP 内で演算により実現している。

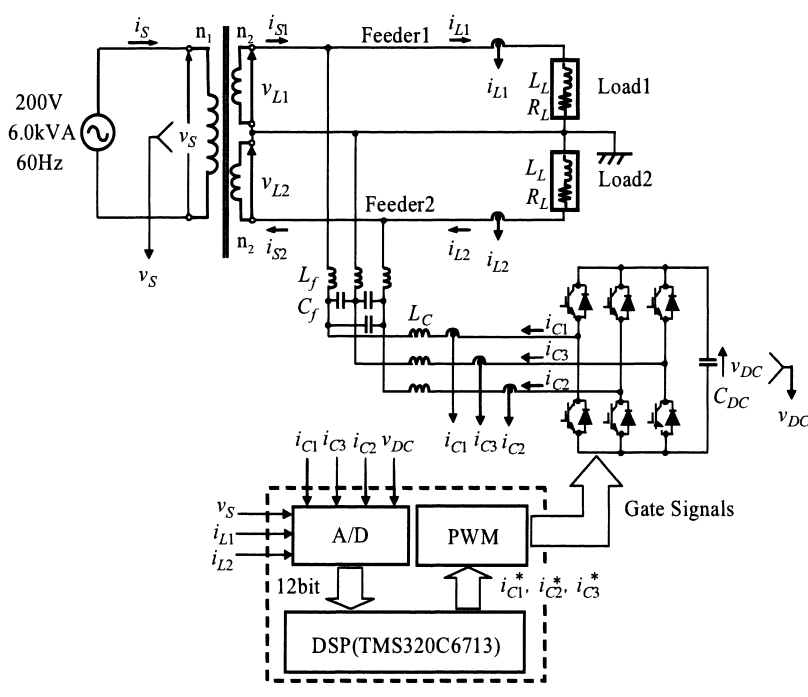

図 5 単相三線式配電用電流バランサの実験装置 構成図

Fig. 5. Circuit diagram of the experimental model for Fig. 1

表 2 図 5 の回路定数

Table 2. Circuit constants for Fig. 5.

\begin{tabular}{ll|l}
\hline \hline Load1 & $L_{L}: 6.4 \mathrm{mH}$ & $L_{f}: 1.0 \mathrm{mH}$ \\
\cline { 3 - 3 } & $R_{L}: 2.9 \Omega$ & $C_{f}: 4.7 \mu \mathrm{F}$ \\
\hline Load2 & $L_{L}: 6.3 \mathrm{mH}$ & $L_{c}: 3.0 \mathrm{mH}$ \\
\cline { 3 - 3 } & $R_{L}: 5.0 \Omega$ & $C_{D C}: 440 \mu \mathrm{F}$ \\
\hline
\end{tabular}

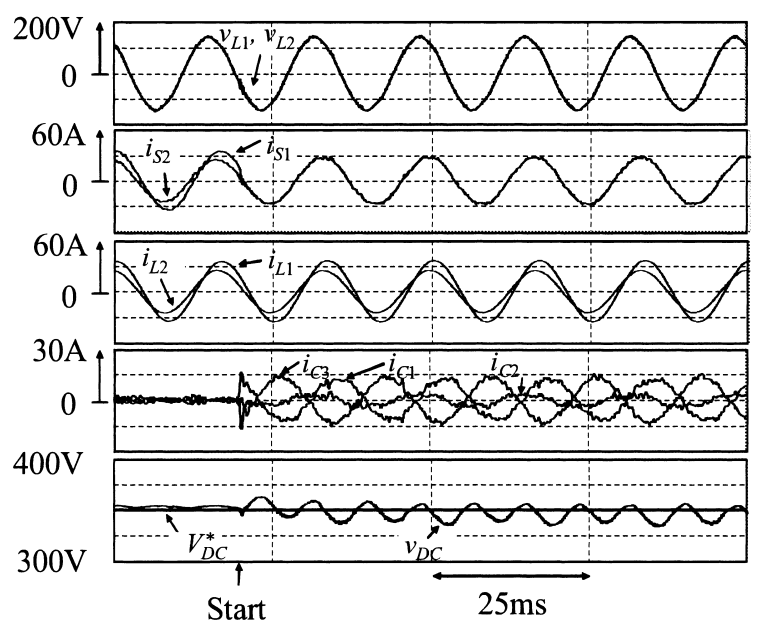

図 6 電流バランサ起動前後の実験波形

Fig. 6. Experimental waveforms for Fig. 5 before and after started.

また，直流キャパシタ電圧一定制御も DSP により実現して いる。

$\langle\mathbf{5} \cdot 2\rangle$ 実験結果 図 6 に, 電流バランサ起動時の実験 結果を示す。 $v_{L 1}$ は低圧側電圧， $i_{S 1}, i_{S 2}$ は各フィーダの電 源電流を示している。電流バランサの起動前は, アンバラン スな負荷状態であるためLoad1 に流れる電流 $i_{L 1}$ と Load2 に流れる電流 $i_{L 2}$ の振幅および位相が異なっている。電流 バランサの起動後は, 電流バランサの補償電流 $i_{C 1}, i_{C 2}, i_{C 3}$ 


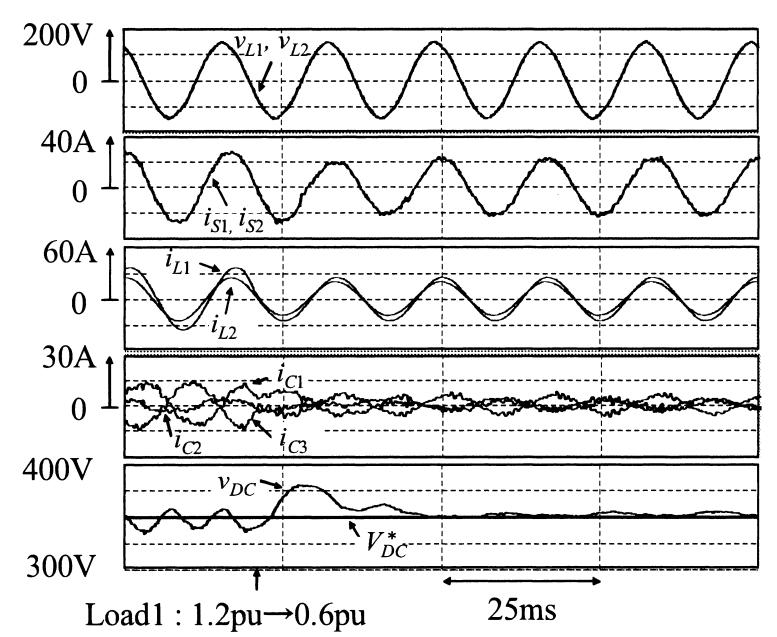

図 7 負荷急変時における実験波形

Fig. 7. Experimental waveforms for Fig. 5 with load variation of the Load1.

により $i_{S 1}$ と $i_{S 2}$ の振幅が等しく力率が 0.9 のバランスした 電流が得られている。また, キャパシタ電圧 $v_{D C}$ から, 直 流キャパシタ電圧一定制御法により指令值 $V_{D C}^{*}=350 \mathrm{~V}$ 付 近に一定に制御されている。

次に, 負荷急変時の実験結果を示す。図 7 は Load2 を一 定とし, Load1 を $1.2 \mathrm{pu}$ から $0.6 \mathrm{pu}$ に急変させた場合の実 験波形である。図 7 より, 負荷が急変した場合においても 電流バランサにより各フィーダの電源電流 $i_{S 1}, i_{S 2}$ はバラ ンス状態となっている。図 6 および図 7 より, 定常状態に おける直流キャパシタ電圧の変動率は $\pm 2.3 \%$ ある。さら に, 負荷急変時のキャパシタ電圧の变動率は+8.3\%であり, $10 \%$ 以となっている。これらの結果はシミュレーション 結果と良く一致しており，計算機シミュレーションにより 決定したキャパシタ容量の妥当性が確認できる。

$\langle\mathbf{5} \cdot \mathbf{3}\rangle$ 変換器容量の検討 ここで, 電流バランサと して動作する電圧形 PWM インバータの変換器容量につい て検討する。低圧側電圧 $v_{L 1}, v_{L 2}$, 電流バランサ出力電流 $i_{C 1}$ および $i_{C 2}$ の実効值をそれぞれ $V_{L}, I_{C 1}, I_{C 2}$ とすると, 各フィーダの皮相電力 $S_{C 1}, S_{C 2}$ は次式で与えられる。

$$
\begin{aligned}
& S_{C 1}=V_{L} \cdot I_{C 1} \\
& S_{C 2}=V_{L} \cdot I_{C 2}
\end{aligned}
$$

したがって, 電流バランサの変換器容量 $S_{C}$ は次式で表さ れる。

$$
S_{C}=S_{C 1}+S_{C 2}
$$

図 3 のシミュレーション結果から， $i_{C 1}$ および $i_{C 2}$ の実効 值はそれぞれ $8.5 \mathrm{~A} ， 3.2 \mathrm{~A}$ である。(22) 式および (23) 式 より変換器容量を求めると $1.2 \mathrm{kVA}$ となり, 負荷容量の約 $23 \%$ ある。一方, 図 6 の実験結果では， $i_{C 1}$ および $i_{C 2}$ の 実効值はそれぞれ8.6 A, 2.9 A であり変換器容量は $1.2 \mathrm{kVA}$ となる。両者は良く一致しており，実験結果の妥当性が確
表 3 直流キャパシタ容量と変換器容量の低減効果

Table 3. Required-rating of the dc capacitor and PWM converter.

\begin{tabular}{c|c|c}
\hline \hline $\begin{array}{c}\text { Source-side } \\
\text { power factor }\end{array}$ & $\begin{array}{c}\text { Capacity of dc } \\
\text { capacitor }[\mu \mathrm{F}]\end{array}$ & $\begin{array}{c}\text { Capacity of PWM } \\
\text { converter }[\mathrm{kVA}]\end{array}$ \\
\hline 1.0 & 750 & 2.7 \\
\hline 0.9 & 440 & 1.2 \\
\hline
\end{tabular}

認できる。今回提案した制御法を用いて電源側の力率を 0.9 とすることで, 先に提案した方式 (3) と比較して変換器容量 を1/2 以下に低減することができた。

\section{6. むすび}

本論文では，3レグ電圧形 PWM インバータを用いた単 相三線式配電用電流バランサの制御法として, 電源電圧と 負荷電流の相関と相互相関に着目した制御法を提案した。 これにより力率が 0.9 でバランスした電流を得ることがで きる点に特長があり，先に提案した方式に比較し変換器容 量を大幅に低減可能である。

はじめに，相関および相互相関関数を用いた電流バラン サの制御法について詳細に検討した。次に, 電圧形 PWM インバータの電力フローおよび直流キャパシタ容量につい て検討し, 先に提案されている方式に比べ直流キャパシタ 容量が低減可能であることを明らかにした。さらに，計算 機シミュレーションおよび実験により, 本論文で提案した単 相三線式配電用電流バランサの有効性を検証した。シミュ レーション結果および実験結果から, 電気供給約款で定め られた力率 0.9 のバランスした電源電流が得られることを 明らかにした。また，先に提案した方式に比較し，変換器 容量および直流キャパシタ容量を約 $1 / 2$ に低減できること を明らかにした。

(平成 19 年 4 月 19 日受付, 平成 19 年 8 月 24 日再受付)

\section{文献}

（1）電気学会：「送電・配電」, オーム社, pp.162-165 (2001)

（2）林泉：「電力系統」, 昭晃堂, pp.86-87 (1978)

(3) H. Fukui, S. Watanabe, E. Hiraki, and T. Tanaka: "A New Control Method of Current Balancer in Single-Phase Three-Wire Secondary Distribution Systems", Papers of Technical Meeting on Semiconductor Power Conversion, SPC-05-60, IEA-05-15, pp.13-18 (2005-6) (in Japanese)

福井博一・渡辺修治. 平木英治. 田中俊彦：「相関関数を用いた単 相三線式配電用電流バランサの制御法」, 電学半導体電力変換研資, SPC-05-60, IEA-05-15, pp.13-18 (2005-6)

(4) T. Tanaka, Y. Nishida, S. Fukuma, and S. Funabiki: "A Novel Harmonic Compersator for Consumer Electric Equipment Using the Correlation Function", in IEEJ Trans. IA, Vol.123, No.11, pp.1377-1383 (2003-11) (in Japanese)

田中俊彦・西田雄治・福間慎治・船曳繁之：「相関関数を用いた家電 機器が発生する高調波の抑制を目的としたアクティブフィルタ」, 電 学論 D, 123, 11, pp.1377-1383 (2003-11)

(5) T. Tanaka, K. Satou, and S. Fukuma: "A Novel Method of Detecting the Active and Reactive Currents in Single-Phase Circuits Using the Correlatin and Cross-Correlation Cofficients", IEEJ Trans. on Industry Appl., Vol.124, No.1, pp.146-147 (2004-1) (in Japanese)

田中俊彦・佐藤邦明・福間慎治：「相関係数と相互相関係数を用いた単 相回路における有効・無効電流検出法」, 電学論 D, 124, 1, pp.146-147 (2004-1) 
（6）中国電力（株）：「電気供給約款」,p.44 (2005)

( 7 ) T. Fujita and S. Iida: "Trial Manufacture of Current Balancer for Singlephase Three-wire Distribution system", in Papers of Technical Meeting on Semiconductor Power Conversion, SPC-04-3, pp.13-18 (2004-1) (in Japanese)

藤田崇之・飯田祥二：「単相三線式配電系統用電流バランサの試作」, 電気学会半導体電力変換研資, SPC-04-3, pp.13-18 (2004)

(8) T. Fujita and S. Iida: "A Current Balancer in Single-Phase Three-Wire Distribution System", in IEEJ Trans. IA, Vol.125, No.12, pp.1145-1152 (200512) (in Japanese)

藤田崇之・飯田祥二：「単相三線式配電系統用電流バランサの一方 式」, 電学論 D, 125, 12, pp.1145-1152 (2005-12)

(9) I. kawasaki, T. Tanaka, S. Fukuma, S. Funabiki: "Discussions on Relationship between the Calculation Time of Harmonic Currents and the DC Capacitance of the Single-Phase Shunt Active Filter using the Correlation Function", in Papers of Technical Meeting on Semiconductor Power Conversion, SPC-04-6, pp.31-36 (2004-1) (in Japanese)

川崎＼cjkstart勇・田中俊彦・福間慎治・船曳繁之：「単相アクティブフィル 夕の高調波検出時間とコンデンサ容量の検討」, 電学半導体電力変換 研資, SPC-04-6, pp.31-36 (2004-1)

（10）電気技術基準調査委員会：「内線規程 JEAC 8001-1995」, 日本電気協 会, p.20
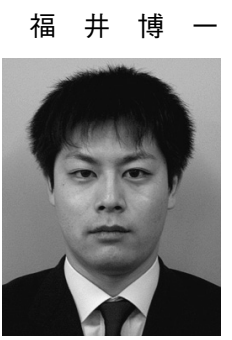

(学生員) 2001 年 4 月島根大学総合理工学部電 子制御システム工学科入学。2005 年 3 月同卒業。 同年 4 月山口大学大学院理工学研究科博士前期課 程電気電子工学専攻入学, 2007 年 3 月同修了。同 年 4 月同博士後期課程情報・デザイン工学系専攻 入学，現在に至る。主に，相関と相互相関に着目 した単相三線式配電用バランサの制御法に関する 研究に従事。

平 木 英 治 (正員) 1990 年大阪大学大学院基礎工学研究科

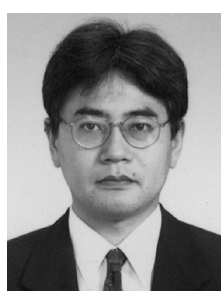
博士前期課程電気工学専攻修了。(株) マツダ技 術研究所を経て, 1995 年 12 月山口大学工学部電 気電子工学科助手, 2006 年 4 月大学院理工学研 究科情報・デザイン工学系専攻助手に配置換え, 2007 年 3 月同助教授，同年 4 月同准教授，現在 に至る。博士 (工学)。主にソフトスイッチング 電力変換システムを含むエネルギーエレクトロニ クスに関する研究と教育に従事。IEEE，パワーエレクトロニクス学会 各会員。電気学会調査専門委員会委員。
田 中 俊 彦 (上級会員) 1984 年 3 月長岡技術科学大学大学

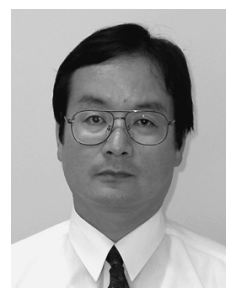
院工学研究科修士課程電気電子システム工学専攻 修了。同年 4 月東洋電機製造（株）入社。職業能 力開発大学校 (現, 職業能力開発総合大学校) 長期 課程部電気工学科講師を経て 1997 年 4 月島根大 学総合理工学部電子制御システム工学科助教授, 2004 年 12 月山口大学工学部電気電子工学科教授, 2006 年 4 月大学院理工学研究科情報・デザイン 工学系専攻教授に配置換え, 現在に至る。博士 (工学)。半導体電力 変換器が発生する高調波とその制御法, 環境修復システムへのパワー エレクトロニクス応用, 微生物処理を含む高度水処理などの研究に従 事。平成 14 年中国電力技術研究財団優秀研究賞, 15 年電気設備学会 学術部門論文賞受賞。電気設備学会, IEEE 会員。

福 間 慎 治 (非会員) 1999 年 3 月長岡技術大学大学院工学

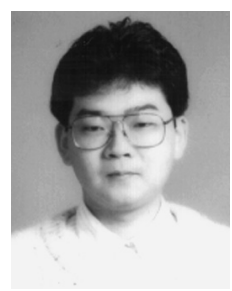
研究科情報・制御工学専攻博士後期課程修了。同 年 4 月同大学工学部電気系助手。同年 9 月通信 · 放送機構研究フェロー兼務。2000 年 4 月島根大学 総合理工学部電子制御システム工学科助手。2004 年 4 月福井大学工学部情報メディア工学科講師, 現在に至る。博士 (工学)。ディジタル信号処理, 適応信号処理，画像符号化，特定用途向けディジ タル画像処理システム構築の研究に従事。電子情報通信学会, 計測自 動制御学会, IEEE 会員。 